\title{
An exploratory study of early letter-sound knowledge in a low socio-economic context in South Africa
}

\author{
SHELLEY O'CARROLL Wordworks (early literacy and language)
}

\begin{abstract}
This paper explores one aspect of early literacy development in a low socio-economic context in South Africa. Assessments conducted with a sample of children from two disadvantaged communities in Cape Town indicated that in this context, almost half of the learners entering Grade One were unable to recognise any letters. A Grade R intervention conducted by volunteers showed that children from this context were able to learn letter-sounds in Grade $\mathrm{R}$ through a programme that focused on teaching letter-sounds in the context of building language skills, emergent writing and concepts about print. In order to strengthen the effectiveness of the intervention, the volunteer programme was supplemented by support for the Grade R teacher and teaching assistant. Follow-up assessments of one of the intervention groups at the end of Grade One revealed significant correlations between early Grade One letter knowledge and end of Grade One word reading and spelling skills. The findings of this exploratory study are in line with research that shows the importance of letter-sound knowledge in the earliest stages of learning to read. This raises concerns about the historical lack of emphasis in the Grade R curriculum on this aspect of early literacy development. Although the study has a narrow focus and conclusions cannot be drawn about other aspects of early literacy learning in this context, the results suggest an urgent need for quality Grade R teacher training programmes with a specific focus on emergent literacy.
\end{abstract}

\section{Introduction}

Provincial and national assessments conducted over the past eight years have confirmed that a high percentage of South African children are not acquiring basic literacy skills in their first three years at school (Department of Education, 2003; Western Cape Education Department, 2009). In an attempt to better understand these low literacy levels, it is useful to not only consider what is happening in schools, but what characterises literacy learning prior to formal schooling. Low literacy levels are not unexpected given that many children 
from disadvantaged communities do not begin school with well established early literacy and language skills (Willenberg, 2004; O'Carroll, 2006; De Witt, Lessing and Lenayi, 2008). This is partly due to the fact that, until recently, many children were not part of a Grade R programme. However, being in a Grade R class does not necessarily guarantee a good preparation for learning to read and write. In a recent study across four provinces in South Africa, De Witt, Lessing and Lenayi (2008) found that although the children in the study attended Grade R classes, they did not display basic early literacy competency. In her study of seven classrooms at five schools in an historically disadvantaged community in the Western Cape, Willenberg (2004: 88) found that the children's pre-school environments offered "inadequate quality and quantity of access to literacy resources and activities". She also expressed concern about the "extent to which teachers are adequately equipped to promote children's language and literacy development" (Willenberg, 2004: 188).

If the focus is to shift from tackling low literacy levels once children have failed to learn to read, to preventing reading failure, there is a need for research evidence on early interventions that are effective in improving early literacy competence. This article focuses on one aspect of an early literacy curriculum: knowledge of letter-sound relationships.

\section{The importance of letter knowledge for learning to read}

A detailed discussion of the merits of 'phonics' and 'whole language' approaches to the teaching of reading is beyond the scope of this article. It is nevertheless important to position the teaching of letter knowledge within the debate about pedagogy. Traditionally, the teaching of letter knowledge would be located in the 'phonics camp'. Whole language theorists have argued that letter cues are not reliable, particularly in a language such as English where letters can represent different sounds. In a whole language approach, children are encouraged to use the context or their prior knowledge to make predictions about words rather than using grapho-phonic cues. However, research on early literacy development suggests that the role of letter knowledge in early reading goes beyond debates about pedagogy. Research has demonstrated that letter knowledge is a necessary foundation for learning to read and write and plays an important role from the earliest stages of literacy development (Ehri,1997; 1998; 2005; Stuart, 1995; Stuart, Masterson and Dixon, 2000).

In the earliest stages of learning to read, emergent readers might initially rely heavily on picture and context cues when reading, but once they know some letter-sounds, they can start to use these as cues to remember words. Although there are many irregular English words where letters do not match sounds, 
English is nevertheless written by means of an alphabetic writing system. The majority of words can be read using letter-sound knowledge, and even an irregular word will have some letters that match the sounds in the spoken words (e.g. yacht). At this stage of their reading development, children are not systematically decoding words, but will be listening for beginning and end sounds in words and looking for letters that relate to these sounds (Ehri, 1995). Ehri (1997: 175) argued:

Readers who can form connections out of partial phonetic cues have an advantage over readers who are limited to visual cues in building a sight vocabulary. This is because phonetic cue readers have a system they can use to remember words. In contrast, visual cue readers have to remember arbitrary, idiosyncratic connections. This makes the words much harder to remember.

Without letter-sound knowledge, and an awareness that letters in written words are related to sounds in spoken language, emergent readers will see reading as remembering a visual sequence of letters using whatever cues are most helpful, such as word length and shape, and shapes of letters (e.g. the word look is often remembered by the two 'eyes' in the middle of the word). These links are arbitrary and are likely to mean that children frequently confuse words having the same letters.

Without letter knowledge, a child cannot begin to experiment with emergent writing and invented spelling. An important stage in the development of written language, invented spelling has also been found to be a predictor of later reading ability. Mann, Tobin and Wilson (1987) used preconventional spelling skills as a predictor of first grade reading ability and tested whether there was an association between performance on a spelling test administered midway through kindergarten and a test of reading ability administered midway through first grade. They established that phonological accuracy scores correlated significantly with word identification and word attack scores. They also found that children who "tend to give a higher proportion of phonologicallyaccurate, preconventional spellings tend to become better readers in the first grade" (Mann et al., 1987: 373).

\section{Letter-knowledge in low socio-economic contexts}

Given the importance of letter knowledge for early reading development, it is of concern that children from high poverty contexts generally begin school with less well-developed letter knowledge than their middle-class peers (Stuart, 1990; Bowey, 1995). Stuart (1990) found that early differences in letter 
knowledge and phonological awareness contributed to differences in early word reading skills and when letter-sound knowledge was used as a predictor of reading achievement, social class was no longer a significant predictor. In another study, Duncan and Seymour (2000) assessed a sample of children between 4 and 8 years of age and found that low socio-economic status was associated with less well-developed letter knowledge, word reading and awareness of sounds. Letter knowledge was the only foundation skill to distinguish socio-economic groups at pre-school and they speculated that "delayed acquisition of foundation literacy skills is traceable to a delay in acquiring letter-sound knowledge" (Duncan and Seymour, 2000: 145).

Is there evidence that intervention programmes that focus on letter knowledge and awareness of sounds are effective in low socio-economic communities, and does increased letter knowledge influence the development of reading and writing skills? Blachman, Ball, Black and Tangel (1994) carried out a classroom intervention with pre-school children from low-income, inner-city classrooms. The intervention was conducted by teachers and classroom assistants in small groups in the classroom during lessons of fifteen to twenty minutes. Before the intervention, the children knew, on average, only two letter sounds. After an eleven week training programme, the intervention group was significantly better than the control group on measures of letter-sound knowledge and breaking up words into sounds. Although the intervention programme did not include any reading or writing, children in the intervention group were able to read significantly more regular words than children in the control group. They also included more letters in their invented spelling.

Tangel and Blachman (1995) were interested in whether the control children would 'catch up' in Grade One. They followed the intervention group children when they started school and found that these children's invented spelling and spelling continued to be better than control-group children at the end of Grade One. These children produced spellings that were at least at the same level and in many cases more complete than those of a middle-class sample (Treiman, 1993). This was an encouraging finding because the children were doing as well as middle-class children, even though they would have had fewer literacy experiences prior to starting school.

In the South African context, two intervention studies have been carried out with Grade One learners. Nadler-Nir (1997) developed a structured programme to teach phonological awareness and letter knowledge to Grade One children from disadvantaged communities and found that the programme was "highly effective in improving phonological awareness, letter knowledge, reading and spelling skills" (Nadler-Nir, 1997: 80). She proposed that the results of the study showed that "phonological awareness and letter knowledge 
training can help disadvantaged children to develop better self-teaching skills for the development of reading and spelling" (Nadler-Nir, 1997: 98). In another study with Grade One children, O'Carroll (2006) found that a short term intervention that included teaching of letter-sound knowledge, phonological awareness, reading and writing was effective in improving the word-reading and -spelling of children relative to a control group of children who started school at a similar level but had no intervention. The children were learning to read and write in English as a second language.

The research is clear: interventions in low socio-economic contexts can make a difference to children's letter knowledge, and this has an impact on levels of early word reading and spelling.

\section{Learning to read in a second language: the role of letter knowledge}

The 'interactive model of reading' used by Gregory (1996) in her work with emergent bilinguals provides a useful framework for considering the role of letter knowledge in learning to read in a second language. The model is concerned with how information such as the structure of language or the meaning of a text (higher levels of processing) influences analysis occurring at lower levels (letter-sound correspondences and word recognition). According to this model, there are four sources of information which children draw upon as they learn to read: lexical knowledge (clues about words); grapho-phonic knowledge (orthographic and phonological knowledge; clues about the patterns of letters in words and the sounds that they make); syntactic knowledge (clues concerning the structure of the language); semantic knowledge (clues concerning the meanings behind the words).

Gregory (1996) proposes that children learning to read in a second language use the same sources of knowledge as their monolingual peers, but that one source of knowledge may compensate for another as they learn in a second language. For example, grapho-phonic knowledge is potentially useful for children who are not proficient in a second language and who cannot rely on semantic and syntactic clues. Children who have the skills to use graphophonic cues will be able to read words that are not in their spoken vocabulary, and if these spoken words are linked to pictures in books, this could be a useful way of adding to their English vocabulary. Gregory (1996) proposes that books are important teachers of a second language to emergent bilinguals. She makes the important point that "children can learn to read before they have oral competence in the target language. Indeed, it is clear that these young children are learning English through their reading. Reading, then, can lead oral language development" (Gregory, 1996: 89). 


\section{Teaching letter knowledge: The South African context}

While few would deny the importance of letter knowledge for learning to read and write, there is much debate about when and how to teach letters. In the Revised National Curriculum Statement, Learning Outcome 3 (Reading and Viewing) includes the following reference to developing letter knowledge in Grade R: "recognises and names some common letters of the alphabet such as the letter the learner's name begins with" (Department of Education, 2003). The recently published Foundations for Learning. Assessment Framework Grade $R$ (Department of Basic Education, 2010) provides more detailed literacy milestones. By Term Three of Grade R, learners are expected to be able to recognise "aurally and visually some initial consonant and vowel sounds especially at the beginning of common words" (Department of Basic Education, 2010: 5), and by the fourth term, they should be able to recognise "aurally and visually, an increasing number of initial consonant and vowel sounds especially at the beginning of common words". The draft Curriculum and Assessment Policy Statement (CAPS) for Foundation Phase, includes similar guidelines

To what extent are these curriculum guidelines reflected in teaching practices in Grade R? A visit to a Grade R class in a middle-class area might reveal opportunities for children to engage with letters in a print rich environment, as well as time allocated to a structured programme to teach letter-sounds. Grade $\mathrm{R}$ teachers would be building on letter knowledge developed through incidental encounters with letters in children's home environments. In middle class contexts, children would know most or all of the letter-sounds by the time they start Grade One. They would be using letters in emergent writing, and as cues to read words in their environment. This is in line with research that has shown that "on the basis of home experiences, middle class children typically start school with a good bit of knowledge about letters and sounds, and thus these children can generally make use of letter-sound correspondences in learning to read" (Wallach and Wallach, 1976: 188). The 'hidden curriculum' in many middle class homes and pre-schools ensures that most children will learn to read at school because they have learnt to read already.

A very different scenario plays out in many pre-schools in disadvantaged communities, where one of the only resources for teaching letters might be an alphabet chart which is used as a stimulus for chanting the alphabet. Teaching letters might typically involve children singing the alphabet song or reciting the names of the letters. Teachers do not always understand the difference between letter-names and letter-sounds, and without opportunities to experiment with sounds in words and see the link to letters, the learning of letters tends to be at a rote level, with little understanding of how sounds in spoken words relate to 
letters in written words. It is not uncommon for children from these contexts to begin Grade One not knowing any letter-sounds at all.

In Willenberg's (2004) study of the emergent literacy skills of children from disadvantaged communities in Cape Town, children were assessed at the end of their Grade R year (mean age of 6 years 2 months). The children in this sample achieved a mean letter recognition score of $7.32(\mathrm{SD}=8.10)$. Scores ranged between 0 and 26 , with $34 \%$ of the children unable to recognise any letters. Willenberg (2004: 191) noted that one of the Grade R teachers in her study reported "being criticised by a curriculum advisor for introducing letter recognition activities to her learners". In a study in a similar context, Nadler Nir (1997) found slightly lower levels of letter knowledge in the first term of Grade One (mean letter knowledge of $5.2(\mathrm{SD}=2.21)$ in an experimental group, and $3.5(\mathrm{SD}=2.93)$ in a control group). In another study in a lower socio-economic group, O'Carroll (2006) tested a sample of 53 children from two schools at the start of their Grade One year (mean age of 6 years 10 months). The mean letter recognition score was $3(\mathrm{SD}=4.62)$. The median score was zero and $43 \%$ of children were unable to identify any letters at all. A further $32 \%$ of children knew between 1 and 3 letters and only a quarter of the sample recognised more than 3 letters.

\section{Study One: Early Grade One letter knowledge in a low socio- economic context}

Study One aimed to establish whether there is evidence that low levels of letter knowledge still prevail in disadvantaged communities. For this purpose, assessments of early Grade One levels of letter-sound were conducted across two different communities in Cape Town.

\section{Participants}

Two schools were selected that serve high poverty communities and are classified as no fees schools. The schools are English medium, with a majority of children who speak English as a second language. According to the provincial Grade Three assessments carried out in 2008, 23.7\% of Grade Three learners at School A were found to have grade appropriate literacy skills. School B opened in 2008, with an intake of learners from Grade R to Grade Three. The 2008 assessments revealed that only $14.3 \%$ of Grade Three learners had grade appropriate literacy skills. 


\section{Procedure and assessment tools}

Children from both schools were tested in February of their Grade One year. As far as possible, scores of children repeating Grade One were not included in the results, although records of previous schooling were often incomplete for children starting school at School B. Children were tested individually by trained volunteers. The assessment was modeled on the Multilingual Phonics Ability Test (Lomofsky, 2004). Children were shown pictures of common items, asked to name them, say the beginning sound of the word and then write the letter for that sound. If they could not name the picture, they were told the name, and if they could not say the beginning sound, the sound was provided for them. Children were not assessed on their knowledge of all of the letters. Ten letters were selected (seven consonants and three vowels - c, $\mathrm{b}, \mathrm{m}, \mathrm{s}, \mathrm{t}, \mathrm{f}, \mathrm{r}, \mathrm{a}, \mathrm{o}, \mathrm{e})$. Reversals in the children's writing were not penalised.

\section{Results}

The children's letter production scores are reported in the table below:

Table 1: Letter production scores of a sample of children from two disadvantaged communities in Cape Town

\begin{tabular}{l|l|l|l}
\hline & Mean age & $\begin{array}{l}\text { Mean letter } \\
\text { writing score } / 10\end{array}$ & $\begin{array}{l}\text { \% of children who } \\
\text { obtained zero }\end{array}$ \\
\hline School A $(\mathrm{n}=85)$ & $\begin{array}{l}\text { 6 years 3 months } \\
\text { 6 years 10 } \\
\text { months }\end{array}$ & $\begin{array}{l}1.7(S D=2.6) \\
\text { School B }(\mathrm{n}=106\end{array}$ & $49 \%$ \\
$42 \%$
\end{tabular}

These results confirm that children in these contexts have limited exposure to letter-sounds in the year before beginning formal schooling.

\section{Study 2: Making a case for early intervention}

In the second part of this paper, the following questions were addressed:

Could letter-sound knowledge be taught in Grade R through a volunteer intervention that included a focus on developing vocabulary, concepts about print, drawing and emergent writing?

Could a Grade R teacher and teaching assistant be supported to teach letter-sound knowledge in the Grade R classroom? 


\section{Participants}

The second part of this study involved an intervention in the Grade R class at School A. The majority of children in the class speak English as a second language. The class is taught by a qualified English speaking teacher with the help of a Xhosa-speaking teaching assistant. Over the past three years, there have been between 47 and 56 children in the Grade R class. There is no postprovisioning for a Grade R teacher, so although School A is a no fees school, fees for Grade R are R30 per month.

\section{Procedure}

In February 2008, 22 learners from the Grade R class were selected to participate in an intervention programme. Children were selected randomly from those who would be turning six years of age during their Grade $\mathrm{R}$ year, and would definitely be going to Grade One the following year. Five children had left the school by the end of Grade R, and a further three children were excluded from this analysis because of high levels of absenteeism during the intervention. An intervention group of fourteen children remained. The children worked in pairs with the same volunteer once a week for thirty to forty minutes, to build their literacy and language skills. On average, each child participated in fourteen lessons during the course of the year (either in the first half or the second half of the year). The volunteers participated in a two hour training session and their teaching was mentored for the first three months of the programme. Neither of the volunteers was a trained teacher, although one had worked at a pre-school.

At the start of Grade One, the fourteen children who had participated in the intervention in Grade R were assessed individually by trained volunteers on measures of letter recognition and awareness of beginning sounds. Only the letter knowledge scores will be reported here. Letter knowledge was assessed using an adapted version of Clay's (1993) Letter Identification Test. Children were shown a card with printed letters and asked what sound the letters made. In an earlier study in this context, this measure proved to be reliable, with an alpha co-efficient of .915 (O’Carroll, 2006).

In 2009, in addition to 18 Grade $\mathrm{R}$ children participating in the volunteer programme, the impact of the intervention was strengthened by giving guidelines to the Grade $\mathrm{R}$ teacher and the teaching assistant for teaching beginning sounds and letter-sound knowledge in the classroom. In February 2009, the Grade R teacher attended a workshop and was provided with some materials for use in the classroom. Two workshops were arranged for teaching assistants 
to demonstrate how to use the intervention programme for teaching small groups in the classroom. The Grade $\mathrm{R}$ teaching assistant was given a pack of resources similar to those used by the volunteers.

\section{Intervention programme}

The volunteer teaching programme was based on an intervention developed as part of a doctoral study in disadvantaged communities in Cape Town (O'Carroll, 2006). The intervention exemplified a balanced approach to teaching early reading by including direct instruction in letter-knowledge and phonological awareness as well as emergent writing and book reading. Each component of the lesson included a focus on building English vocabulary and spoken language. Materials and resources for the lessons were developed for the local context. Lessons typically followed the following format:

1. Talking about a book or reading a story to develop language and concepts about print

2. Drawing and emergent writing in response to the book

3. Games to develop vocabulary, awareness of beginning sounds, lettersound knowledge and blending and segmentation skills (syllables and phonemes).

Letter-sound knowledge and awareness of beginning sounds were taught through the following activities: naming objects and pictures and identifying beginning sounds; sorting tasks to classify objects and pictures according to their beginning sounds and letters; forming letters using different media: playdough, whiteboards, sand; games to reinforce letter-sounds using picture cards: bingo, memory games, board games; making little alphabet books.

\section{Results}

Assessments at the start of Grade One in 2009 indicated that the average letter knowledge of the 14 children who participated in the intervention in Grade $\mathrm{R}$ was $11.86(S D=6.18)$. The scores ranged from $3-23$. It was evident that lettersounds could be taught in Grade R in this context, through a short term, low cost intervention.

The results of the assessments of the Grade One cohort the following year (2010) are tabulated below. Comparisons between three groups are possible: those that had attended Grade R at School A and participated in the volunteer 
intervention; those that had attended Grade R at school A but did not work with volunteers; and those children that had attended community pre-schools or had no pre-school experience at all.

Table 2: Letter identification scores of children at the start of Grade One (2010)

\begin{tabular}{|c|c|c|c|}
\hline & \multicolumn{2}{|c|}{ Grade $\mathrm{R}$ class (School A) } & \multirow[b]{2}{*}{$\begin{array}{l}\text { Other pre-schools/ } \\
\text { no pre-school } \\
\text { (n=79) }\end{array}$} \\
\hline & $\begin{array}{l}\text { Volunteer } \\
\text { Intervention } \\
(\mathrm{n}=18)\end{array}$ & $\begin{array}{l}\text { No intervention } \\
(\mathrm{n}=15)\end{array}$ & \\
\hline Mean age & 6 years 4 months & 6 years 3 months & 6 years 3 months \\
\hline $\begin{array}{l}\text { Mean letter } \\
\text { identification } \\
\text { score }\end{array}$ & $\begin{array}{l}15.6 \\
(S D=6.7)\end{array}$ & $\begin{array}{l}6.9 \\
(S D=7.4)\end{array}$ & $\begin{array}{l}1.86 \\
(\mathrm{SD}=1.86)\end{array}$ \\
\hline
\end{tabular}

These results confirm the effectiveness of the volunteer intervention in teaching letter-sound knowledge. Comparisons of mean scores of the two groups of learners in the Grade R class at School A indicated that the intervention group mean was significantly better than the average of the group who only received classroom teaching of letter-knowledge $(t=3.5, p=.001)$. The ratio of one adult to two children provides an optimal context for learning, and a programme that is delivered by volunteers is a cost-effective model.

Significant differences were also found between the mean letter-knowledge scores of the two groups who did not participate in the volunteer intervention: those in the Grade R class at School A and those learners who attended other pre-schools or had no pre-school experience $(\mathrm{t}=.2 .57, \mathrm{p}=.021)$. This result is not surprising, and it would be assumed that children who are part of a Grade $\mathrm{R}$ class at a school would have an advantage. However, this is not necessarily the case. In the baseline tests conducted in February 2008, there were no significant differences between the mean letter knowledge scores of children who had attended the Grade R class and those from other pre-schools/no pre-school (mean letter identification scores: Grade R class at School A $=1.76$ $(S D=2.17)$; Other pre-schools/no pre-school mean score $=1.41(S D=2.11)$, $\mathrm{t}=.667, \mathrm{p}=.507)$.

\section{Study 3: An early advantage?}

The third part of the paper explores whether there was any link between the letter knowledge scores of a sample of children at the beginning of Grade One and their word reading and writing levels at the end of Grade One. Would 
children's letter knowledge as measured by their response to an intervention in Grade $\mathrm{R}$ be a useful indicator of further progress in Grade One?

\section{Context}

The 2008 intervention group $(\mathrm{n}=14)$ had been assessed at the start of Grade One in 2009. The children were all in the same Grade One class of fifty children and were taught by an experienced Grade One teacher. She had been trained in the Concentrated Language Encounter (CLE) approach and regularly included language experience activities in her lessons (Walker et al., 1984). One of the regular CLE lessons began with the teacher asking the children a question and encouraging them to give a verbal response. One of the children's responses was then chosen to be written by the teacher on newsprint and illustrated by the child for the 'Daily News'. A new page was added in the next lesson, and news from previous lessons was read by the children.

Letter-sounds were taught throughout the year through an alphabet chart and small group activities, using letters printed on cards. The children were introduced to word-level reading through 'sound families' and spelling patterns ('mat, fat, cat, hat, bat, pat'). The children did not have their own readers and the text from a book was usually written on the board and then the teacher pointed to the words while the children read in chorus.

\section{Procedure and assessment tools}

The children's letter knowledge was tested at the start of their Grade One year, using an adapted version of Clay's (1993) Letter Identification Test (refer to Study 2). Fourteen children were re-tested at the end of their Grade One year on a letter writing test in which the tester says a word, then reiterates the initial sound of the word and asks the child to write the letter for that sound (Hannavy, 1993). Standardised word-reading and -spelling tests were also administered. The Burt Word Reading Test (Gilmore, Croft, and Reid, 1981) and the BAS Spelling Test (Elliot, 1996) were selected for this purpose. These measures had proven to be reliable measures in a similar context when administered to Grade One children midway through the year (O'Carroll, 2006).

\section{Results}

Correlations between scores on a test of letter recognition at the start of the year, and tests of letter writing, word reading and spelling at the end of the year are presented in the table below. 
Table 3: Correlations between scores on tests of letter knowledge, spelling and word reading

\begin{tabular}{l|c|c|c}
\cline { 2 - 4 } & \multicolumn{3}{c}{ Tests conducted in November 2009 } \\
\cline { 2 - 4 } & Letter Production & Spelling & Word Reading \\
\hline $\begin{array}{l}\text { Letter Identification } \\
\text { (February 2009) }\end{array}$ & $.87^{\star \star}$ & $.88^{\star \star}$ & $.82^{\star \star}$ \\
& & &
\end{tabular}

** Pearson's correlation is significant at the 0.01 level (2-tailed).

These correlations are in line with the research literature and indicate that the children who had good letter knowledge at the start of Grade One were also those who had good word reading and spelling scores at the end of Grade One, while those who started with limited letter knowledge achieved low scores on tests of basic word level skills a year later. As a measure of response to intervention, the February letter knowledge scores partly reflected children's capacity for learning. Therefore it would not be surprising that those who had made the most gains in letter knowledge, also made the most gains in learning to read and write in Grade One.

Children who learnt their letters more quickly in Grade R might well be those that were more responsive to teaching. However, their good foundation of letter knowledge would have meant that they would have gained more from literacy learning opportunities in the classroom. Learners who started Grade One with a solid foundation of letters could use these letters as cues to support early word-learning. Learners with limited or no letter-sound knowledge would have been forced to learn words using arbitrary visual cues. They would also have to learn spellings of words by rote, whereas children with lettersound knowledge might have been able to listen for sounds in words and represent these with known letters. This seems to be a case of the 'Matthew Effect' in which the rich get richer and the poor get poorer (Stanovich, 1980).

When the children were grouped according to their early Grade One letter knowledge, they fell into three distinct groups at the end of the year. The small size of the sample meant that statistical analysis of group differences was not possible. However, the following table shows interesting trends. 
Table 4: End of Grade One letter writing, word reading and spelling scores by group

\begin{tabular}{l|c|c|c} 
& $\begin{array}{l}\text { Group 1 } \\
(\mathrm{n}=4)\end{array}$ & $\begin{array}{l}\text { Group 2 } \\
(\mathrm{n}=4)\end{array}$ & $\begin{array}{l}\text { Group 3 } \\
(\mathrm{n}=6)\end{array}$ \\
\hline $\begin{array}{l}\text { Letter identification score } \\
\text { (February) }\end{array}$ & $3-8$ letters & 9-12 letters & 14-23 letters \\
\hline $\begin{array}{l}\text { Mean Letter Writing score } \\
\text { (November) }\end{array}$ & 10.0 & 20.3 & 24.2 \\
\hline $\begin{array}{l}\text { Mean Word Reading score } \\
\text { (November) }\end{array}$ & 0.5 & 4.5 & 10.8 \\
\hline $\begin{array}{l}\text { Mean Spelling score (November) } \\
\text { Nean }\end{array}$
\end{tabular}

Given the small sample size, the table above needs to be interpreted with caution. However, the pattern that emerges is that in this sample, limited early letter knowledge placed children at risk for reading failure, and a solid foundation of letter knowledge gave children a good chance of learning to read and write at the appropriate level by the end of Grade One (test norms indicated children who have spent a year at school should be able to read 18-24 words and spell 9-12 words). The words of Willenberg (2004: 203) are apt: "(t)he developmental trajectory of most children appears to be well established at school entry. However, although it has been found that good teaching can improve a child's developmental trajectory, what seems to happen more commonly is that schooling simply reinforces the emerging developmental trends and usually widens the gap between good and poor readers."

\section{Discussion}

The results of this exploratory study confirm the findings of a small body of research in the South African context, indicating that Grade R children from disadvantaged communities are not beginning school with well-established letter knowledge. A small scale intervention showed that this is not because the children in this context are incapable of learning letters until they start Grade One, but because they are not being taught. This is partly due to a lack of locally developed, cost-effective resources and a lack of knowledge about how to teach letter-sounds as part of a meaningful, child centered curriculum. However, one of the reasons why many teachers have not focused on teaching letter knowledge in Grade $\mathrm{R}$ is because of a lack of emphasis on this aspect of literacy learning in the curriculum. Curriculum guidelines indicate that Grade R children should know 'some' letters by the time they start Grade R, but it would seem that the teaching of letter-knowledge is regarded as being primarily the responsibility of Grade One teachers. Priority is not given to the 
teaching of letters in Grade $\mathrm{R}$ and the associated advantages of this important foundation remain a 'middle class secret'. The curriculum does not serve to level the playing fields for children from low socio-economic contexts.

South African curriculum documents are specific about the sequence and pace of teaching letter knowledge in Grade One. According to the Foundations for Learning. Assessment Framework Foundation Phase, children should be able to identify the letter-sound relationships of five consonants and five vowels by the end of Term One of Grade One, and the letter-sound relationships of all single sounds by mid-year of Grade One (Department of Basic Education, 2008). The teaching of letter-sound knowledge in Grade One is done in parallel with teaching reading and writing of words, with pressure to meet the demands of the Grade One curriculum. Not only are children expected to learn ten lettersounds by the end of the first term of Grade One, they are also expected to learn twenty-five sight words and build up short words using sounds learnt, e.g., c-a-t, cat. Observations of children learning-to-read show that it can be a challenge to retrieve the sounds of newly acquired letters, while simultaneously having to blend these sounds to make a word. Research on developmental change has shown that newly acquired knowledge can be difficult to apply to new tasks (Karmiloff-Smith, 1992; 1994). Miller and Coyle (1999: 218) propose that "a certain amount of quantitative change in expertise may be required before qualitative shifts in the organisation of this knowledge can occur".

Many middle class children from four to six years of age learn letters in the homes, through incidental encounters with print and participate in a Grade $\mathrm{R}$ programme that includes teaching of letters and many opportunities to experiment with hearing sounds in words. This means that by the time they start Grade One, letter-sound knowledge will be a well established system of knowledge, which can be applied to new tasks such as 'building short words'. Children from disadvantaged communities are expected to acquire the same knowledge in the first six months of Grade One, while simultaneously using this newly acquired knowledge to learn to read and write words. In this regard, Ferreiro and Teberosky (1982: 280) have argued that "school is directed to those who already know. Success in learning depends on the child's condition when he or she begins receiving instruction". As it stands, the Grade One curriculum is geared towards middle class children who are learning letter-sounds in the years before schooling - at home and in Grade R - and are therefore at a significant advantage when they start Grade One. It is no surprise that children who have a good foundation of letter knowledge by the end of Grade R, are able to move quickly through the Grade One curriculum, whereas those who start Grade One with limited letter knowledge, struggle to learn twenty-six letters by the end of the second term, and have great difficulty in applying this new knowledge to tasks such as building words. 


\section{Conclusion}

The narrow focus of this article on one aspect of early literacy development in a specific context means that it is not possible to draw conclusions about other important foundations for literacy learning. At best, it might be the case that letter knowledge is simply one area of early literacy that is particularly poorly taught in Grade R. At worst, low levels of letter knowledge might well be symptomatic of a general lack of emphasis on language and literacy learning in Grade R. While, for the foreseeable future, many children will continue to be disadvantaged by contextual factors, quality ECD programmes can play a critical role in leveling the playing fields and giving children from disadvantaged communities a fair chance of success. In her extensive analysis of programmes that are effective in closing the poverty gap, Neumann (2009) argues that high quality early childhood programmes are non-negotiable if children from disadvantaged communities are going to have a chance of success. In South Africa, this is echoed by Du Plessis (2001: 186-187) who proposes that "educational policy should therefore advocate that these children need better than average pre-school literacy introduction", including a "specified curriculum for the introduction of emergent literacy". Although the focus in the ECD sector has been on getting children into Grade R classes, quality of provision is key to closing gaps for children from high poverty contexts. In this regard, Willenberg (2004: 192) argues that "although providing access to Grade R instruction is critical, that access will have no value unless it provides high quality curriculum and instruction". Quality of provision rests on teacher training that includes a strong emergent literacy component.

In a country where the vast majority of children do not begin school well prepared to learn to read and write, the Grade R curriculum has a key role to play in closing gaps for children who do not come from print-rich homes. This does not mean that teachers need to introduce formal learning situations that are inappropriate for Grade R. Letters and sounds can be taught through play and in the context of developing children's vocabulary and awareness of sounds in words. It is critical that the Grade R curriculum gives teachers clear messages about important foundations for literacy that need to be laid in Grade R. Otherwise the curriculum serves to perpetuate the status quo. Starting off with limited early literacy skills, children from disadvantaged backgrounds are not able to meet the demands of the Grade One curriculum, and this sets them off on a path towards reading failure. 


\section{References}

Ball, E., and Blachman, B. 1991. Does phoneme awareness training in kindergarten make a difference in early word recognition and developmental spelling ? Reading Research Quarterly, 25: 49-66.

Blachman, B. A., Ball, E. W., Black, R. S., and Tangel, D. M. 1994. Kindergarten teachers develop phoneme awareness in low-income, inner-city classrooms. Does it make a difference ? Reading and Writing: An Interdisciplinary Journal, 6: 1-18.

Bowey, J. A. 1995. Socioeconomic status differences in pre-school phonological sensitivity and first grade reading achievement. Journal of Educational Psychology, 87(3): 476-487.

Chiappe, P., Siegel, L. S., and Gottardo, A. (2002). Reading-related skills of kindergartners from diverse lingusitic backgrounds. Applied Psycholinguistics, 23: 95-116.

Clay, M. 1993. An observation survey of early literacy achievement. Auckland, New Zealand: Heinemann.

Department of Basic Education. 2008. Foundations for Learning Assessment Framework Foundation Phase. Pretoria: Department of Basic Education.

Department of Basic Education. 2010. Foundations for Learning Assessment Framework Grade R. Pretoria: Department of Basic Education.

Department of Basic Education. Curriculum and assessment policy statement (CAPS). Foundation Phase Home Languages. Grades R- 3. Final draft. http://www.thutong.doe. gov.za/Thutong/PolicyDocuments/FoundationPhase/tabid/4751/Default.aspx

Department of Education. 2003. Systemic Evaluation 2003: Foundation Phase. Pretoria: Department of Education.

Department of Education. 2003. Revised National Curriculum Statement Grades R-9. Teachers Guide for the development of learning programmes. Pretoria: Department of Education.

De Witt, M., Lessing, A. and Lenayi, L. 2008. An investigation into the state of early literacy of pre-school learners. Journal for Language Teaching, 42(2): 1-10.

Dixon, M., Stuart, M., and Masterson, J. 2002. The relationship between phonological awareness and the development of orthographic representations. Reading and Writing: An Interdisciplinary Journal, 15: 295-316.

Duncan, L., and Seymour, P. 2000. Socio-economic differences in foundation-level literacy. British Journal of Psychology, 91:145-166.

Du Plessis, E. 2001. A conceptual framework for accelerating emergent literacy skills of disadvantaged pre-schoolers. PhD dissertation, University of Pretoria.

Ehri, L. 1995. Phases of development in learning to read by sight. Journal of Research in Reading, 18:116-125.

Ehri, L. 1997. Sight word learning in normal readers and dyslexics. In B. Blachman (Ed.), Foundations of reading acquisition and dyslexia (pp. 163-189). London: Lawrence Erlbaum and Associates.

Ehri, L. 1998. Grapheme-phoneme knowledge is essential for learning to read words in English. In Word recognition in beginning literacy, J. Metsala and L. Ehri (eds.). Mahwah, NJ: Lawrence Erlbaum Associates, 3-40.

Ehri, L. 2005. Learning to read words: Theory, findings and issues. Scientific Studies of Reading, 9(2): 167-188.

Elliot, C. D. 1996. British Ability Scales II. Windsor: NFER Nelson. 
Ferreiro, E., and Teberosky, A. 1982. Literacy before schooling. Portsmouth, NH: Heinemann. Gilmore, A., Croft, C., and Reid, N. 1981. Burt word reading test. New Zealand Revision. Wellington: New Zealand Council for Educational Research.

Gregory, E. 1996. Making sense of a new world: learning to read in a second language. London: Chapman.

Hannavy, S. 1993. The Middle Infant Screening Test and Forward Together Programme. Teacher's guide. Windsor: NFER-Nelson.

Karmiloff-Smith, A. 1992. Beyond modularity: A developmental perspective on cognitive science. Cambridge, MA: MIT.

Karmiloff-Smith, A. 1994. Self organisation and cognitive change. In Brain Development and Cognition, M. H. Johnson (ed.). Cambridge, MA: Basil Blackwell, 592-618.

Lomofsky, L. 2004. Multilingual Phonics Ability Kit. Cape Town: University of the Western Cape.

Mann, V., Tobin, P., and Wilson, R. 1987. Measuring phoneme awareness through invented spellings of kindergarten children. Merrill-Palmer Quarterly, 33, 365-391.

Miller, P. H., \& Coyle, T. R. 1999. Developmental change: Lessons from microgenesis. In Conceptual development: Piaget's legacy, E. K. Scholnick, K. Nelson, S. A. Gelman and P. H. Miller (eds). Mahwah, NJ: Erlbaum, 209-239.

Nadler-Nir, E. 1997. The effectiveness of a multi-sensory phonological awareness and letter knowledge training programme for disadvantaged first graders. MSc dissertation, University of Cape Town.

Neuman, S. (2009). Changing the odds for children at risk. Seven essential principals of educational programs that break the cycle of poverty. Westport: Praeger Publishers.

O'Carroll, S. 2006. Supporting early literacy development in a disadvantaged community in SA. Focus on developmental change. PhD dissertation, London University.

Stanovich, K. E. 1980. Towards an interactive-compensatory model of individual differences in the development of reading fluency. Reading Research Quarterly, 19: 32-71.

Stuart, M. 1990. Factors influencing word recognition in pre-reading children. British Journal of Psychology, 81: 135-146.

Stuart, M. 1995. Prediction and qualitative assessment of five- and six-year old children's reading: a longitudinal study. British Journal of Educational Psychology, 65: 287-296.

Stuart, M., Masterson, J., and Dixon, M. 2000. Spongelike acquisition of sight vocabulary in beginning readers? Journal of Research in Reading, 23 (1): 12-27.

Tangel, D. M., and Blachman, B. A. 1992. Effect of phoneme awareness instruction on kindergarten children's invented spelling. Journal of Reading Behaviour, 24(2): 233-261.

Tangel, D. M., and Blachman, B. A. 1995. Effect of phoneme awareness instruction on the invented spelling of first-grade children: a one-year follow-up. Journal of Reading Behaviour, 27(2): 153-185.

Treiman, R. 1993. Beginning to spell. New York: Oxford University Press.

Wallach, M., and Wallach, L. 1976. Teaching all children to read. London: University of Chicago Press.

Western Cape Education Department. 2009. Media release: Western Cape's literacy and numeracy challenges, from http://wced.school.za/comms/press/2009/75_14july.html

Willenberg, I. 2004. Getting set for reading in the rainbow nation. Emergent literacy skills and literacy environments of children in South Africa. PhD dissertation, Harvard University. 
Acknowledgements: The writing of this article was made possible by a grant from the DG Murray Trust. The opinions expressed in the article are not necessarily those of the funders. 
